\title{
Halk Kütüphanelerinde Bebek Kullanıcılara Yönelik Hizmetler
}

\section{Services for Baby Users in Public Libraries}

\author{
Ayşenur Güneş ${ }^{1}$ (i), Mehmet Canatar²
}

'Sorumlu yazar/Corresponding author:

Ayşenur Güneş (Araş. Gör.)

Kastamonu Üniversitesi, Edebiyat Fakültesi, Bilgi

ve Belge Yönetimi Bölümü, Kastamonu, Türkiye

E-posta: akbulutaysenur@gmail.com

ORCID: 0000-0002-8685-7712

${ }^{2}$ Mehmet Canatar (Prof. Dr.),

İstanbul Üniversitesi, Edebiyat Fakültesi, Bilgi ve Belge Yönetimi Bölümü, İstanbul, Türkiye

E-posta: canatar@istanbul.edu.tr

ORCID: 0000-0002-6070-8903

Başvuru/Submitted: 04.01.2020

Revizyon Talebi/Revision Requested: 20.03.2020

Son Revizyon/Last Revision Received: 13.05 .2020

Kabul/Accepted: 27.05 .2020

Atıf/Citation: Gunes, A. ve Canatar, M. (2020). Halk kütüphanelerinde bebek kullanıcılara yönelik hizmetler. Bilgi ve Belge Araștırmaları Dergisi, 13 55-80. https://doi.org/10.26650/bba.2020.13.03
ÖZ

Halk kütüphaneleri, hizmet sunduğu kullanıcı kitlesi en geniş kütüphane türüdür. Bebeklikten başlayarak, tüm yaş gruplarına hizmet sunan halk kütüphanelerinin ülkemizdeki durumu sorgulandığında diğer yaș gruplarına göre bebeklere yönelik hizmet çeșitliliğinin fazla olmadığı görülmektedir. Yurt dıș literatürde "baby friendly- bebek dostu" olarak adlandırılan bu kütüphane türü ülkemizde henüz yeni gelişmekle beraber hızlı bir şekilde yayılmaktadır. Kültür ve Turizm Bakanlığı bu konunun önemini dikkate alarak Karabük Zübeyde Hanım İl Halk Kütüphanesi ve Şarköy İlçe Halk Kütüphanesinde ilk olarak bebek bölümlerini hizmete sunmuştur. Çalışma kapsamında ülkemizde bebekler için ayrı bölümleri olduğu saptanan iki halk kütüphanesinin ilişkili bölümleri kütüphanelerin beş temel unsuru (bütçe, mekân, kullanıcı, personel, derme) bağlamında incelenmiștir. Halk kütüphanesi kapsamı dıșında müstakil bir binada ve halk kütüphanesinden bağımsız olarak hizmet sunan bebek kütüphanesi örneklem dışında kaldığından araştırma kapsamına alınmamıştır. Çalışmada nitel araştırma yapılmıştır. Durum çalışması uygulanması aşamasında, veri toplama tekniği olarak ise yapılandırılmış görüşme ve doküman incelemesi teknikleri uygulanmıştır. Verilerin değerlendirilmesi aşamasında ise betimsel analiz tekniğinden yararlanılmıştır. Gerçekleştirilen değerlendirmeye göre her iki kütüphanenin de eksikleri olmasına karşın işbirliği ve paylaşımlarla geliştirilebilecek olan bu hizmeti ülkemizde ilk olarak sunmuş olmaları önem arz etmektedir. Ayrıca, bebek bölümlerinin kütüphane kullanıcıları tarafindan yoğun bir şekilde kullanıldığı ve yaygınlaştırılması gerektiği şeklinde olumlu dönütler alındığı bilgisi elde edilmiștir

Anahtar kelimeler: Bebek kütüphaneleri, Bebek dostu kütüphane, Halk kütüphanesi

\section{ABSTRACT}

When the status of public libraries serving all age groups in Turkey is questioned, it is seen that there is not much variety of service for babies compared to other age groups. Taking into account the importance of this issue, the Ministry of Culture and Tourism has carried out studies to provide services for babies in libraries. Within the scope of this study, the relevant sections of two public libraries in Turkey, which were found to have separate sections for babies, were examined in the context of the five basic elements of libraries (budget, location, user, staff, collection). Since libraries for infants, which serve in a detached building outside the public library and independent from it, were excluded from the sample, they were not included in the research. Qualitative research was conducted in the study. During the case study implementation, structured interview and document review techniques were used as the data collection technique. At the stage of data evaluation, descriptive analysis technique was used. The result of the study showed that the sections for infants were used extensively by users of the library and positive feedback was received from the users.

Keywords: Baby libraries, Baby friendly library, Public library 


\section{EXTENDED ABSTRACT}

Until recently, not many library services have been designed for the baby user group . As consideration of baby users has increased, the concept of a library for infants has emerged in recent years. This concept has led to some conceptual confusion in the literature, but nonetheless a type of library has emerged for babies who are already within the service of public libraries. The term "baby friendly", already in use in foreign literature, was preferred instead of the concept of "baby library" within the scope of this study. Although library services for the baby group under twelve months of age, also referred to as pre-walkers, are quite limited, babies in this age group constitute the user group that needs utmost attention in terms of safety. Although providing services for this age group is challenging for libraries, it should be kept in mind that the mentioned age group is the most important period in an individual's life. When it is considered that habits such as using libraries and reading books are very early acquired behaviors, the importance of libraries for babies becomes apparent. In our country, spaces known as 'baby-friendly' have started to appear in public libraries: Karabük Zübeyde Hanım Provincial Public Library and Şarköy District Public Library are two examples of this. In this study, two baby sections that serve within the scope of a public library were examined. The aim of the study was to determine the service qualities of the baby sections and to reveal the importance of these sections. A qualitative research method was used in the study. Structured interview and document analysis techniques were used in the study in which a case study method was applied. Structured interview questions consisting of 12 questions and directed to both libraries, were sent to the library administrators via e-mail and data were collected. In the light of the data obtained, although both libraries were established with the support of the Ministry of Culture and Tourism, the most important feature of Karabük Zübeyde Hanım Provincial Public Library is that it was established in cooperation with the Department of Child Development and Education of Karabük University and takes support from this department while providing its services. Among other findings, this study concludes that baby departments are visited with interest by families and that they are satisfied with the service provided. Both libraries serve babies aged 0-3 and do not have separate staff for this department. While an average of 6-7 babies use Şarköy District Public Library per day, an average of 30 babies use Karabük Provincial Public Library. Karabük Zübeyde Hanım Provincial Public Library and Şarköy District Public Library, evaluated within the scope of the study, are the first examples in our country to put the concept of a baby-friendly library into practice. Karabük Zübeyde Hanım Provincial Public Library provides this service cooperatively by receiving the support of the Department of Child Development of Karabük University. This not only ensures that the collection is of high quality and rich in materials for babies, but also increases the quality of the service. Also, the availability of a separate baby care room can be shown as a result of this cooperation. This is because the needs of this age group were clarified by taking the opinions of experts into account (child developers, educators, etc.) and necessary arrangements were 
made. The fact that Şarköy District Public Library is located in a small district and therefore has limited opportunities can be shown as its negative aspect. Despite being in a small district, the high usage rates reveal the importance of this place for that area. The lack of a separate baby care room can be regarded as the most important deficiency of this library. It is clearly understood how important these, and similar contributions, are especially for small provinces and districts that are relatively devoid of many opportunities rather than areas with more opportunities such as developed metropolises. Although there are many facilities that families can avail themselves of with their babies in big cities, such facilities are either limited or not available in small places. At this point, when we consider public libraries in the context of socialization, the necessity of designing areas for babies becomes more apparent. While many elements related to library services designed in such areas are fulfilled, it is very important to constantly pay attention to hygiene in order to ensure the continuity of these services. It should not be forgotten that the health and physical development of the age group being served are essential for the basis of their development in many areas such as cognitive and mental areas. Individuals who have grown up in the library environment since infancy will regard the library as a natural environment and this will make them good library users. 
"Çocuklara yatırım yapmak için onların birer yetişkin olmasını bekleme lüksümüz olmadiğı gibi, onlar okula başlayana kadar bekleme lüksümüz de yok, çünkü o zaman müdahale etmek için çok geç olabilir"

James Heckman

\section{GİRIŞ}

Çocuk kütüphanelerinin kullanıcı grubunu; bebekler ve küçük çocuklar, 13 yaşına kadar olan okul çocukları, özel gereksinimi olan gruplar, ebeveynler ve diğer aile üyeleri, bakıcılar, kitap ve medya alanlarında çalışan yetişkinler oluşturmaktadır (Yılmaz ve Ekici, 2011, s. 547). IFLA rehberinde çocuk kütüphanelerinin hedef kitlesinin bu şekilde nitelenmesine karşın son yıllara değin çocuk kütüphaneleri sadece okul öncesi yaş grubuna ait materyalleri barındırmakta idi. Son yıllardaki mesleki gelişmelere paralel olarak hem yurtdışında hem de ülkemizde "bebek kütüphaneleri” ismi ile bebeklere yönelik hizmetler sunulmaya başlanmıştır. Yılmaz (2019), bebek kütüphanelerine ilişkin kaleme almış olduğu yazıda, bebek kütüphanesi kavramını eleştirmiş, yurtdışı literatürde "bebek dostu kütüphane” kavramının kullanıldığını dile getirmiş ve bebekler için ayrı bir kütüphane türü olmasının mesleki açıdan mümkün görünmediğini ifade etmiştir.

Çocuk ve halk kütüphanelerinin kullanıcı kitlesine baktığımızda bebeklere hizmet yükümlülügüünü görmekteyiz. Bu nedenle Yılmaz'ın görüşlerine katılarak, bu hizmetin bir kütüphane türü değil, çocuk kütüphanelerinde bebek yaş grubuna yönelik koleksiyon oluşturma ve onların en etkin şekilde bu mekânları kullanabilmeleri için mekân tasarımının yeniden düzenlenmesi olarak değerlendirilmesinde yarar olduğu düşünülmektedir. Bu bağlamda çalışmanın başlığında kavram karmaşasına yol açmamak adına bebek kütüphaneleri yerine çocuk kütüphaneleri kapsamında bebek kullanıcı grubu ifadesinin kullanımı tercih edilmiştir. $\mathrm{Bu}$ kapsamda bebek ve çocuk bölümlerini içerisinde barındıran halk kütüphaneleri; yer aldığı toplumun bütün üyelerinin her türlü bilgi ihtiyacını karşılamaya yönelik hizmet sunan kurumlardır. İlk kuruldukları günden bu yana bilgi kaynağı (kitap, dergi, gazete vb. basılı ve elektronik materyal) sağlama misyonunu yüklenmişlerdir. Halk kütüphaneleri, son yıllarda üçüncü mekân olgusu ile birlikte, sosyalleşme alanı olarak daha fazla anılır olmuş ve hayatımızın önemli bir parçası halini almaya başlamışlardır.

\section{Halk Kütüphanelerinin İşlev ve Sorumlulukları}

Çalışma kapsamında öncelikle halk kütüphanelerinin işlev ve sorumluluklarına kısaca değinilmesi yararlı görülmüştür.

IFLA/UNESCO Halk Kütüphanesi bildirgesinde (Gill, 2004, s. 22) halk kütüphaneleri şu şekilde tanımlanmaktadır: 
Yerel, bölgesel, ulusal ya da başka tür kamu kuruluşları tarafından kurulan, desteklenen, finanse edilen; bilgi ve hayal gücü olan birçok kaynağa hizmetleri aracılığıyla erişimi sağlayan; ırk, yaş, din, dil, cinsiyet, ulus, yetersizlik, ekonomik ve iş durumu ve eğitim farkı gözetmeksizin toplumun bütün üyelerine eşit hizmet sunan kurumlardir.

Osman Ersoy (1983, s. 2) halk kütüphanelerini; “yaygın eğitimin, halk eğitiminin en iyi aracı, en güçlü silahı olup, halkın bilgi, beceri, kültür alanındaki her çeşit gereksinimini karşılayan bir halk Üniversitesi' dir” şeklinde tanımlamaktadır.

Halk kütüphaneleri, yukarıda verilen iki tanımda da görüldüğü gibi, yer aldıkları bölgenin bütün bireylerinin her anlamda bilgi ihtiyacını karşılayan kurumlardır. Halk kütüphaneleri, bilgi okuryazarlığı eğitiminden sanat eğitimine kadar çok yönlü konularda hizmet sunmaktadır. Bu bağlamda bakıldığında Ersoy’un tanımında vurguladığ “"Halk Üniversitesi” terimi uygun düşmektedir.

Halk kütüphanelerinin hizmet ve işlevlerini daha iyi anlamak ve anlatmak için beş temel unsur bağlamında incelenmesi gerekmektedir: Bütçe, bina, derme, personel ve kullanıcı.

\subsection{Bütçe}

Halk kütüphaneleri amaç ve işlevlerini yerine getirmek, toplumun bilgi ihtiyacını karşılamak ve topluma faydalı olabilmek amacıyla belirli bir bütçeye ihtiyaç duymaktadır (Özdemirci, 1989, s.38). IFLA’nın yukarıda verilen tanımında da yer aldığı gibi ücret alınmadan sunulan hizmetin karşılığında hem kurum giderlerinin karşılanması hem de koleksiyonun geliştirilmesi ve hizmet sunulması için gerekli bütçenin oluşturulması gerekmektedir.

IFLA/UNESCO (Gill, 2004, s. 48) ilkelerinde halk kütüphanelerinin bağlı bulunduğu Bakanlık tarafından belirlenen genel bütçesi dışında mali kaynakları şu şekilde açıklanmaktadır:

- Bireylerin ya da kurumların bağışları,

- Ticari etkinliklerden elde edilen gelirler (sanat ve el işi, yayın satışı vb.),

- Ödünç kitap geciktirme cezaları,

- Fotokopi gibi hizmetlerden alınan ücretler,

- Diş kuruluşların desteği,

- Özel öncelikler için piyango gelirleri.

Bütün bu gelirlerin kütüphane yönetimi içerisinde harcandığı kalemleri şu şekilde sıralayabiliriz: Personel giderleri, kullanıcı için ayrılan gider, teknik donanım ve yazılım giderleri, derme sağlama giderleri (Campbell, 1992, s. 83). 
2012 yılında Kültür ve Turizm Bakanlığı Kütüphaneler ve Yayımlar Genel Müdürlüğü (KYGM) tarafindan yayımlanan "Kütüphane Hizmet Esasları" isimli genelgede "Bütçe" başlığı altında; Türkiye genelinde hayata geçirilmesi istenen tasarruf tedbirleri nedeniyle bütçe olanaklarının sınırlandırıldığı, azami tasarruf anlayışı ile hizmet öncelikleri ve zorunlu ihtiyaçların göz önünde bulundurulması ve ödeneklerin öncelikle kullanıcının hizmetine sunulan alanlarda kullanılması gerektiğine ilişkin maddeler yer almaktadır (KYGM, 2012a, s. 5-6). 2012 yılında, tasarruf tedbirleri amacıyla, bütçe planlamasında yapılan değişiklikte, kullanıcılara sunulacak hizmetlerde bir aksama yaşanmaması adına kullanıcıların hizmetine sunulan alanlar için ödeneklerin öncelikli olarak kullanılması kararı alınmıştır.

Bütçe konusu, hizmet sunan ve bu hizmet karşılığında bir gelir (kazanç) elde etmeyen kurumlar için önemli bir unsurdur. Hizmetin sağlanabilmesi için gereken bütçenin kütüphanenin bağlı olduğu kurum tarafından eksiksiz ve özenli bir şekilde tahsis edilmesi gerekmektedir. IFLA/UNESCO tarafından kurum bütçesi haricinde sağlanan mali kaynaklar ise seçenek olmakla birlikte her dönem düzenli bir şekilde elde edilecek bir kaynak olarak görülmemelidir.

Halk kütüphanelerine yapılacak her türlü yatırımın, eğitim öğretime yapılan yatırımlar gibi sonuçlarının uzun vadede alınacağı unutulmamalıdır (Ersoy,1983, s. 4). Bu nedenle, halk kütüphanelerine ayrılacak bütçenin ve mali kaynakların en üst seviyede tutulması, o bölgenin eğitim ve kültürüne yapılmış en büyük yatırım olarak görülmelidir.

\subsection{Mekân}

Halk kütüphanelerinde mekân ve bina tasarımı son yıllarda Kültür ve Turizm Bakanlığı tarafından dikkate alınan bir konu olmuştur. Gerek kütüphanelerin toplum gözündeki imajını tazelemek ve güçlendirmek, gerekse son y1llarda gündeme gelen üçüncü mekân kavramı ve kütüphanelerin sosyal yaşam alanları şekline gelmesi ile ilgili olarak yapılan çalışmalar bu konunun önemini ortaya koymaktadır.

Son yıllarda halk kütüphanelerinin bina tasarımı konusunda işlevsel kullanımı dikkate alınarak iç ve dış özellikleri açısından ilgi çekici şekilde planlanmasına önem verilmektedir. (Sağlamtunç, 1994, s. 106). Kültür ve Turizm Bakanlığı Kütüphaneler ve Yayımlar Genel Müdürlüğü tarafından 2017 yılında düzenlenen "Halk Kütüphanelerinde Mimari Uygulamalar Çalıştayı" ülkemizin bu konuya önem verdiğini ve halk kütüphanelerinde iyi yönde bir gelişme olacağına dair umut vermektedir. Çalıştay’ın ikinci grubunun konusu olan Kütüphane Binalarının Mimari Özellikleri başlığı altında; üçüncü mekân olgusu çerçevesinde bir iletişim ve sosyal merkez olarak tasarlanması gerektiği, bina tasarımında bölgesel etkenlerin (iklim, nüfus yoğunluğu, bölgesel mimari vb.) dikkate alınması gerektiği ve bu nedenle de tip projelerden kaçınılması gerektiği, her türlü doğal afet durumuna karşı güvenli binalar yapılması ve güvenlik 
tedbirlerinin alınması gerektiği, engelli kullanıcıların ihtiyaçları doğrultusunda bina tasarımı yapılması gerektiği gibi birçok sonuç ortaya konmuştur (KYGM, 2017, s. 9-11).

Halk kütüphanesi olgusu, üçüncü mekân, modern kütüphane binaları ve yeşil kütüphane anlayışı ile değişime uğramıştır. Kullanıcı odaklı bu gelişmeler ile beraber kullanıcıların halk kütüphanelerini ergonomik, kullanışlı, sıcak ve çekici bulması sonucunda kütüphane kullanımı artmış ve kütüphaneye bakış açıları değişmeye başlamıştır. Dolayısıyla kütüphanelerin mimari tasarımı kullanıcı potansiyelini arttırması açısından oldukça önemlidir.

\subsection{Derme}

Halk Kütüphaneleri, dermelerinin gelişimi bakımından tutarlı bir yaklaşıma sahip olmak için yönetsel organ tarafından onaylanmış bir derme yönetim politikasına gereksinim duyar (Gill, 2004, s. 94). Kütüphanelerin derme oluşturması ve geliştirmesi, bir standarda bağlı olarak kullanıcıların bilgi gereksinimleri doğrultusunda yapılmalıdır. Bu nedenle bağlı oldukları kurumlar tarafından onaylı bir politika olması önemlidir.

Derme, etkili ve verimli hizmet sunulabilmesi için kütüphanelerin en önemli unsurudur. Halk kütüphaneleri her yaştan kullanıcıya hizmet sunduğundan kapsamlı bir dermeye sahip olmalıdır. Halk kütüphaneleri; kitap, süreli yayın, dergi, gazete, görsel işitsel kaynaklar, veri tabanları vb. kaynakları içermektedir (Cengiz, 2017, s. 13). Son yıllarda kütüphaneler hizmetlerini çeşitlendirdiğinden derme özellikleri de değişiklik göstermektedir. Halk kütüphaneleri bilgi kaynakları dışında gündelik yaşamda ihtiyaç duyulan ekipmanları da ödünç verebilmektedir (Torun, 2018, s. 246). Bu nedenle kütüphanelerin dermeleri çeşitlenerek; geleneksel bilgi kaynaklarına yenileri eklenmekte ve bunlara ek olarak geleneksel olmayan materyaller de (müzik aletleri, oyuncak vb.) kütüphanelerde yer almaktadır.

KYGM tarafindan 2012 yılında yeniden düzenlenen kütüphane hizmet esasları genelgesine göre; yayın seçme komisyonu öncelikli olarak okuyucu istekleri ve talepleri doğrultusunda, ihtiyaç duyulan yayınları belirleyerek derme geliştirmelidir. Ayrıca, çocukların ruhsal ve fiziksel gelişimlerine katkı sağlamak amacıyla uygun oyuncaklar ve görsel işitsel materyallerin alımına öncelik verileceğine ilişkin hükümler yer almaktadır (KYGM, 2012a, s. 8). Bu genelgede açıkça görülmektedir ki; kütüphanelerin değişen yapısına, gelişen koleksiyonlar da eklenmiştir. Oyuncak vb. materyallerin alımının gereğine genelgede açık bir şekilde yer verilmiştir.

\subsection{Personel}

Personel olgusu, hizmet sunan bir kurum için önemlidir. Özellikle kütüphane gibi toplumun büyük bir kesimi tarafından ön yargı ile bakılan ve içine girilmesi konusunda dahi kayg1 hissedilen kurumlar için personel nitelikleri ve yaklaşımları dikkatle ele alınmalıdır. Kütüphane kaygısı konusunda yapılan çalışmalar, kütüphane personelinin bu kaygıları anlamasını, onları 
gidermesini ve kullanıcıların kütüphaneden kaygı duymamasını sağlamak konusunda önemli görülmektedir (Yılmaz, 2011, s. 380). Bu bağlamda halk kütüphanelerinde çalışacak personelin hem mesleki bilgi ve deneyiminin yeterli olması hem de iletişim becerilerinin iyi olması beklenmelidir.

IFLA/UNESCO Halk Kütüphaneleri İlkelerine göre halk kütüphanesi personelinden aşağıda yer alan bilgi ve becerilere sahip olması beklenmektedir:

- Olumlu yönde iletişim kurabilme yeteneği,

- Kullanıcı gereksinimlerini anlama yeteneği,

- İşbirliği yeteneği,

- Mesleki bilgi, deneyim ve beceri,

- Kütüphane hizmet ilkelerini anlama,

- Etkili kütüphane hizmeti sağlamak için diğerleriyle çalışma yeteneği,

- Örgütsel beceriler,

- Yeni fikirlere açık olma ve hayal gücü,

- Çalışma yöntemlerini değiştirmeye hazır olma,

- Bilgi ve İletişim teknolojileri becerisi (Gill, 2004, s.112-113)

Yukarıda yer alan becerilerin tümü halk kütüphanelerinde kullanıcılara daha etkin, verimli ve yenilikçi hizmet sunulabilmesi için önemlidir. Bu çerçevede halk kütüphanelerinde çalışacak personelin öncelikle mesleki eğitim almış olması, hem söz konusu ilkeleri sağlaması hem de kullanıcılarına iyi hizmet sunması adına gereklidir.

\subsection{Kullanıcı}

Kullanıcı olgusu, diğer dört unsurun buna bağlı olarak işlev görmesi nedeniyle en önemli unsurdur. Halk kütüphanesi kullanıcıları, diğer kütüphane türlerine göre daha karmaşık bir demografik yapıya sahiptir. IFLA/UNESCO ilkelerine göre halk kütüphanesi potansiyel kullanıcıları üç kategoride incelenmiştir:

- Her yaştan bireyler (çocuk, genç yetişkin, yetişkin)

- Özel gereksinimi olan bireyler (engelliler, etnik gruplar, azınlıklar vb.)

- Topluluktaki daha büyük kurumlar (yönetimsel organlar, iş çevresi vb.) (Gill, 2004, s. 55).

Halk kütüphaneleri gerek şube ve gezici kütüphaneler ile gerekse geçici dermeler ile bütün bu gruplara hizmet sunmaktadir. 
Kütüphanelerde, "bebek kullanıcılar” yeni bir kavram olarak literatüre geçmiştir (Knoll, 2016). Bebeklere yönelik sunulacak kütüphane hizmetlerine ilişkin yapılmış çalışmalara literatürde rastlanmamıştır. Yapılan taramalarda, yurtdışında yazılmış birkaç kitap bulunmuştur. Ülkemizde ise bu grup, çocuk kütüphaneleri içerisinde değerlendirilmekte ancak daha önce söz edildiği gibi bebeklere ilişkin özel çalışmalar bulunmamaktadır. 2019 yılında gerçekleştirilen ilk "Bebek Kütüphaneleri Çalıştayı" (Haberler ve Duyurular, 2019) ile birlikte bu kavram literatürümüzde yer almaya başlamıştır. Bu kapsamda çalışmanın konusu bebekler olduğundan bebeklerin hangi yaş gruplarını kapsadığı ve gereksinimlerini açıklamakta fayda görülmektedir.

\section{Halk Kütüphanelerinde Kullanıcı Grupları}

Kütüphaneler için kullanıcı; hizmet vermek için hedeflediği grubun üyeleri ve kütüphane derme ve hizmetlerini kullanan bireylerdir (American Library Association, 1983, s. 237). Kullanıcı olarak tanımlanan bireyler kütüphane hizmetlerinden yararlanan ya da yararlanma olasılığı bulunan (potansiyel kullanıcı) bireyler olarak açıklanabilir. Potansiyel kullanıcı olarak tanımlanan grup; halk kütüphaneleri için toplumun tamamını ifade etmektedir. Çünkü halk kütüphaneleri toplumun tamamına hizmet sunmakla yükümlüdür (Rowley, 2000, s. 158). Bu sebeple kütüphaneyi kullanmasalar dahi kullanma olasılığı bulunan toplumun tüm bireyleri halk kütüphanesi için potansiyel kullanıcıdır.

Potansiyel kullanıcı dışında aktif (reel) kullanıcı olarak tanımlanan grup ise; hizmetlerin sunulması için hedef alınan, aktif kullanıcı topluluğu şeklinde açıklanmaktadır (Biblarz, Bosch ve Sugnet, 2001, s. 57). Hizmet tasarlama ve geliştirme sürecinde hem potansiyel hem de aktif kullanıcıların beklenti ve istekleri göz önüne alınmalıdır. Kullanıcıların bilgi arama davranışları konusunda yapılan bir çalışmada, potansiyel kullanıcıların ilgi ve ihtiyaçlarının belirlenmesinin aktif kullanıcılar için yapılan çalışmalardan daha önemli olduğu vurgulanmıştır (Özlük, 2006, s. 112). Kütüphaneyi henüz kullanmamış potansiyel kullanıcıların kütüphaneye ilgilerinin çekilebilmesi toplumda yer alan her bireyin kütüphanenin aktif kullanıcısı olabilmesi açısından önemlidir.

Her yaş grubundan bireye hizmet sunmakla sorumlu olan halk kütüphaneleri günümüzde daha çok eğitim amaçlı olarak öğrenciler tarafından kullanılmaktadır (Uçak ve Topçu, 2012, s. 1). Bu sebeple kütüphaneyi çalışma ortamı olarak kullanan aktif kullanıcılar ve hiç kullanmayan potansiyel kullanıcılar için hizmetlerin tanıtımı önem arz etmektedir.

Halk kütüphanesi kullanıcıları, IFLA/UNESCO (Gill, 2004, s. 55) tarafından hazırlanan rehberde şu şekilde gruplandırılmaktadır:

- Her yaştan bireyler.

o Çocuklar.

o Genç yetişkinler. 
o Yetişkinler.

- Özel gereksinimi olan birey ve gruplar.

o Farkl1 kültürlerin ya da etnik grupların bireyleri.

o Engelliler.

o Eve bağımlı insanlar.

o Kurumsal bağımlı bireyler (hastane, cezaevi vb.).

- Topluluktaki daha büyük kurumlar.

o Eğitimsel, kültürel ve gönüllü organizasyonlar.

o İş çevresi.

o Yönetsel birim.

Görüldüğü gibi halk kütüphanelerin çok geniş bir kullanıcı grubu bulunmaktadır. Çalışma kapsamında bebek kullanıcı grubu hedef alındığından çocuk kullanıcı grubu incelenecektir.

\subsection{Kullanıcı Grubu Olarak Çocuklar}

Çocuk kullanıcı grubuna yönelik hizmetlerin daha net anlaşılabilmesi için çocuk gelişim özelliklerinin belirtilmesinde yarar görülmektedir.

Birleşmiş Milletler Çocuk Haklarına Dair Sözleşme’nin 1. maddesine göre; “18 yaşına kadar her insan çocuk sayılır” (B.M., 1989). Çocukluk olarak adlandırılan dönem farklı şekillerde gruplandırılmaktadır (bilişsel olarak, gelişim özelliklerine bağlı vb.). Ünlü eğitimci Jean Piaget (1896-1980) bilişsel gelişimi 4 evrede sınıflamaktadır:

- Duyusal Dönem 0-2 yaş

- İşlem Öncesi Dönem 2-7 yaş

o Sembolik (kavramsal öncesi) dönem (2-4 yaş)

o Sezgisel dönem (4- 7 yaş)

- Somut İşlem Dönemi 7-12 yaş

- Soyut İşlem Dönemi 12+ şeklindedir (akt. Kol, 2011, s. 4).

Piaget'in sınıflamasına göre dönemler bilişsel gelişim bağlamında çocukluk dönemlerini kapsamaktadır. Dönemlere verilen isimler çocukların bilişsel olarak sahip oldukları özellikleri işaret etmektedir. Mesleki Eğitim ve Öğretim Sisteminin Güçlendirilmesi Projesi (MEGEP) (2009) kapsamında yapılan bir diğer sınıflama ise şu şekildedir:

- Bebeklik Dönemi 0-2 yaş

- Oyun Çağı 2-6 yaş 
- Okul Çağı 6-12 yaş

- Ergenlik Dönemi 13-19 yaş (MEGEP, 2009).

Çocukluk dönemlerinin açıklanmasında MEGEP tarafından yapılan sınıflandırma çocukların genel gelişim özelliklerini yansıttığından tercih sebebi olmuştur.

Bebeklik Dönemi (0-2 yaş): Çocuğun hayatında en önemli evredir. Bu dönemde hızlı bir nörolojik gelişim söz konusudur. Çocuk hem yürümeyi, hem de konuşmayı bu dönemde öğrenir (Vural, 2013; akt. Güller ve Bilbay, 2016, s. 400). Kendi bedenini ve dış dünyayı keşfetmede duyularını (görme, işitme, tat alma, koklama, dokunma) ve motor becerilerini kullanır. Genel özellikleriyle bu dönemde çocuklarda şu gelişmeler gözlenir:

- Dünyaya geldiğinde net görüşe sahip olamayan bebekler, dördüncü ayın sonunda net görmeye başlarlar.

- Çok küçük bebekler konuşma seslerini algılayabilirler.

- Bebekler kokuları ayırt edebilirler.

- Yeni doğmuş bebekler hem tatlı hem de ekşi ve biberli gibi tatlara duyarlıdırlar.

- Doğumdan sonraki ilk ay anne, baba ve çocuk arasındaki bağın oluştuğu dönemdir.

- Bu dönemde hızlı bir gelişim gösterirler, ellerini kullanabilme, oturma, ayakta durma, yürüme gibi gelişmeler gösterirler (MEGEP, 2009, s. 16-19).

Bu dönemde çocuklarda gözlenen bir diğer davranış ise refleksif dönemden amaçlı davranışa geçmesidir (Kol, 2011, s. 4). Artık davranışlarını ve hareketlerinin bir amacı vardır.

Oyun Çağı (2-6 yaş): Çocukların oyun çağında, motor becerileri gelişmektedir. Sayı sayma, şarkı söyleme, şiir okuma ve soru sorma gibi alanlarda becerileri oluşmaya başlar. Artık diş dünyaya hâkimdir ve kendisini birey olarak görür. 2-4 yaş hareketliliğin arttığ1 ve duyguların inişli çıkışlı olduğu bir dönemdir (MEGEP, 2009, s. 19). Bu dönem çocuklar hayatın onun etrafında döndüğü düşüncesiyle hareket ederler. Bu dönemde dil gelişimi hızlıdır, sınıflama becerileri yoktur (Kol, 2011, s. 4-5). 3-6 yaş arasındaki çocukların karakterinin biçimlenmesi, fiziki ve zihni olarak harcadığı kişisel çabaların desteklenmesi gerekmektedir (Durakoğlu, 2011, s. 136). Bu dönemde çocuklar artık bireydir ve kendi istekleri ve beğenileri söz konusudur. Kendisi dışında bir dünya yoktur. Okul öncesi dönem (0-6 yaş) çocuğun dil ve bilişsel gelişiminin büyük ölçüde tamamlandığı dönemdir (Kol, 2011, s. 2).

Okul Çağı (6-12 yaş): Bu dönem çocukların okul ile tanıştıkları ve eğitim hayatlarının başladığı dönemdir. Bu dönemde çocuklar, gerekli fiziksel becerileri öğrenme, kendi bedenini benimseme, sosyalleşme, cinsiyetine uygun davranma, okuma yazma becerileri, vicdan, ahlaki değerler sistemi gelişimi, bireysel davranma, sosyal grup oluşturma gibi gelişmeler gösterirler (Bacanlı, 2011, s. 56-57). Okul ve eğitim ile tanışan çocuk bu dönemde 
kendi özel alanını edinir (arkadaş çevresi ve okul ortamı). Okul çağı olarak adlandırılan bu dönemde çocuklar;

- Büyük ve küçük kaslarını kullanmayı öğrenir,

- Kurumsal kurallara uyarak yaşamayı öğrenir,

- Yaşıtlarıyla birlikte oynamayı öğrenir,

- Bedenine bakma ve temizlik alışkanlığı kazanır,

- Kendi davranışlarının sorumluluğunu yüklenebilir,

- Somuttan soyuta doğru düşünme yeteneği kazanır (MEGEP, 2009, s. 21).

Ergenlik Dönemi (13-19 yaş): Bu dönem çocukluktan çıkma ve yetişkin olma arasında kalmış bir geçiş dönemidir. Ergenlik döneminde kız çocukları ve erkek çocukları fizyolojik olarak farklı gelişim özellikleri gösterirler. Bilişsel olarak bakıldığında ise; her durumda kendi düşüncelerinin doğruluğuna inanır (Kol, 2011, s. 6) ve çevresindeki kişilerle özellikle ailesiyle tartışma halindedir. Bu dönem yetişkinliğe hazırlık dönemi olarak tanımlandığından çocuk, bu dönemde evlilik ve aile hayatına hazırlanma, bir meslek için hazırlanma, sorumluluk yüklenme eğilimi gibi belirtiler gösterirler (Bacanl1, 2011, s. 59).

Çalışmanın bu bölümünde üzerinde durulması gereken kütüphane hizmetlerinden yararlanan bebek kullanıcılardır. Yukarıda söz edilen çocukluk dönemleri içerisinde yer alan bebeklik dönemine ilişkin bilişsel gelişim ile beraber bebeklerin kütüphane hizmetlerinden yararlanma durumlarından söz edilecektir.

\subsection{Kütüphane Kullanıcıları Olarak Bebekler}

İnsan yaşamında, emekleme dönemi (infancy) ile 2-4 yaş arası çocukluk dönemi (toddlerhood) oldukça önemli görülen zaman dilimleridir. Kütüphane ve Bilgi Bilimi (LIS) dişında, gelişim psikolojisi, erken çocukluk eğitimi, sosyoloji, antropoloji ve sağlık bilimleri disiplinleri sürekli ve yoğun bir ilgi ile bu dönemler üzerinde durmaktadır (McKechnie, 2006, s. 191). Genel bir çerçeve ile okul öncesi dönem olarak adlandırılan ve 7 yaş öncesi olarak tanımlanabilen (yukarıdaki zaman dilimlerini de içine alan) dönem, bir bireyin, fiziksel, ruhsal, bilişsel olarak gelişimini etkileyen, hayatındaki en önemli dönemlerdendir. Bu süreçlerde yaşanan olumsuz olayların (istismar, şiddet gibi) bireyin yaşamı boyunca kalıcı etkiler bıraktığı bilinmektedir (Bertan, Haznedaroğlu, Yurdakök ve Güçiz, 2009, s. 2). Olumsuz etkilerin yaşam boyunca bırakacağı olumsuz izler gibi olumlu anlamda yapılan her eylem, bireyin hayatında olumlu izler bırakacaktır.

Bireyin dünyaya geldikten sonraki ilk 2 yıl bebeklik, 3-6 yaş ilk çocukluk (oyun), 7-11 yaş ikinci çocukluk, 12-18 yaş ergenlik dönemi olarak kabul edilir (Çadem, 2019). Buna göre, bebek olarak nitelediğimiz grup 0-2 yaş dönemini kapsamaktadır. Bu noktada kütüphanelerde bebeklere yönelik hizmet dendiğinde 2 yaş ve altı kullanıcı grubu akla gelmektedir. Bu yaştaki 
kullanıcı grubuna hizmet sunmak çok önemli görülmekle birlikte bir yaş altı yani yürüme öncesi grup olarak adlandırılan (pre-walker) daha küçük kullanıcılar için azami derecede dikkatli olunması gerekmektedir (Marino, 2003, s. 1). Bir yaş altı olarak sınıflandırılan ve yürüme öncesi (pre-walker) olarak nitelenen bebek grubu için kütüphane hizmetleri oldukça sınırlı olmasına rağmen, bu dönemdeki bebekler güvenlik açısından en çok dikkat edilmesi gereken kullanıcı grubunu oluşturmaktadır. Bu yaş grubu için hizmet sunmak her ne kadar kütüphaneler için zorlayıcı da olsa, anılan dönemin bireyin yaşamında en önemli dönem olduğu unutulmamalıdır. Bu bir yıllık süreçte bebeklerin çevrelerindeki her şeyi özümsedikleri ve bu bilgilerin yaşamları boyunca onlarda iz bıraktığı bilinmektedir (Marino, 2003, s. 3). Alışkanlıklar, bireylerin küçük yaşlardan itibaren sürekli uygulayarak edindiği davranışlardır. Bebeklik dönemiyle birlikte sürekli kütüphane kullanmaya başlayan birey, kütüphaneleri doğal yaşamının bir parçası olarak algılar. Nasıl ki bebeğin yaşamında sürekli ziyaret edilen akraba, komşu ve arkadaş evleri doğal ve gidilmesi gereken ortamlar durumuna geliyorsa, kütüphaneler de bebeklikten başlayarak sürekli ziyaret edildiği zaman, benzer biçimde doğal ortamlara dönüşebilmektedir. Yine, ebeveynler, bakıcılar ya da aile büyükleri (kendilerine bakan ve güven duydukları kişiler) ile birlikte sürekli bir biçimde gidilen bu mekânlar bebekler için kendilerini güvende hissettikleri ve mutlu oldukları yerler olmaktadır.

Tekiner (1997) tarafından yapılan araştırma sonuçlarına göre 0-6 yaşına kadar alınan eğitimin 18 yaşına kadar gösterilen okul başarısının \%33'ünü etkilediği belirtilmektedir (akt. Ramazan ve Demir, 2011, s. 84). Ebeveynlerin çocuklara kitap okumaya başlamaları için ideal yaşın şu ana dek öngörülen 3 ile 5 yaş arası değil, doğumu ve hatta daha öncesini de kapsaması gerektiği (Naylor, 1987, s. 383) görüşü de dâhil bütün bilgiler göstermektedir ki sadece okul dönemi değil bireyin dünyaya geldiği ilk andan başlayarak yaşadığı deneyimler, edindiği bilgi ve beceriler onun yaşamı boyunca başarısızlığının ya da başarılı olmasının temelini oluşturacaktır.

İngiltere'de ilk olarak uygulanan "İlk Kitabım” projesi ile amaçlanan 0-12 aylık bebeklere ve 1-3 yaş arası çocuklara içerisinde kitap, kütüphane üyelik kartı ve kütüphane tanıtımlarının yer aldığı broşür vb. ürünler içeren çanta verilerek, kütüphaneye davet edilmekte ve bu konuda bilinçlenmeleri sağlanmaktadır (Gürbüz, 2015, s. 171). Bu uygulama ile küçük çocukların özellikle bebeklerin kütüphane kullanmalarına ne derece önem verildiğini göstermektedir.

Bebeklik dönemi de dâhil olmak üzere; ebeveynler, çocuklar için en önemli okuma rol modelleridir. Küçük çocuklar ile ebeveynleri ve bakıcıları arasında bu bağlamdaki erken etkileşimler kişisel, sosyal, kültürel, duygusal ve dilsel gelişimlerine önemli katkı sağlamaktadır. Ebeveyn ya da bakıcı ile birlikte okumak ve kitap paylaşmak, iletişim becerilerini geliştirmeye yardımcı olan konuşmayı teşvik etmektedir. Ailelerde paylaşılan kitap okuma, okul başarısı, okuryazarlık, kimlik ve aidiyet kazanma ve okuryazar toplumlara/topluluklara katılım ile güçlü bir şekilde bağlantılıdır (Rankin, 2016, s. 2). 
“Erken Çocukluk Döneminde Kütüphane ve Dil Gelişim” isimli çalışmada; erken çocukluk döneminde sıklıkla ziyaret edilen kütüphane ve kitapçıların çocukların dil ve okuryazarlık gelişimini olumlu yönde etkilediği tezinden yola çıkılarak, kütüphanelerin böyle bir etki bırakmadığı sonucuna ulaşılmıştır. Bunun nedenleri ise araştırma yapılan bölgede yer alan çocuk kütüphanelerinin çocuğun yaş ve gelişimsel özelliklerine göre yetersiz olması yani çocuk dostu olmaması ve ailelerin kütüphaneyi tercih etmemesi biçiminde açıklanmıştır (Işıklığlu, 2016, s. 1903). Bu bağlamda bakıldığında, halk kütüphanelerinin hizmet planlarını ve tasarımlarını, önemli bir kullanıcı grubu olan bebeklerin ihtiyaçlarına ve özelliklerine yönelik yapmasında "bebek dostu kütüphane" olgusunun ne kadar önemli olduğu ortaya çıkmaktadır. Unutulmamalıdır ki kütüphaneler, her bireyin eşit bir şekilde ziyaret edebildiği kurumlar olarak tanımlanmaktadır (Marino, 2003, s. 1). Bu nedenle, hem sosyo-ekonomik durum hem de yaş aralıkları açısından bakıldığında bu eşitliğin sağlanması için gerekenler yerine getirilmelidir.

Dünya genelinde çocuk kütüphanelerinde genel bir değişim söz konusudur. Kütüphaneler hizmetlerini ve dermelerini daha erken yaş gruplarını da (0-2 yaş) dikkate alarak çeşitlendirmektedir (Odabaş ve Akkaya, 2019, s. 121). Özellikle bilgi kaynaklarının değişimi ve çeşitlenmesi, bütün kütüphane türlerinde olduğu gibi çocuk kütüphanelerinde de değişime neden olmuştur. Çocuk kütüphanelerinde yaşanan bu değişim unsurlarında 3 özellik bulunmaktadır:

- Zengin aktivite merkezleri

- Mekânsal farklılaşma

- Bölgenin gönüllüleri ve yöneticileri gibi dinamiklerle işbirliği (Odabaş ve Akkaya, 2019, s. 85).

Bu değişim unsurları içerisinde bebeklerin yoğunlukla kullandığı (oyuncak, dokun hisset kitapları vb.) materyaller kütüphane içerisinde yer almaktadır. Değişen derme yapısı ve mekânsal farklılaşma sonucu bebekler ve aileleri (bakıcıları) kütüphaneyi daha rahat bir şekilde kullanabilmektedirler. Bebeklere hizmet sunmaya başlayan kütüphaneciler artık bir bebeğin gelişimi üzerindeki rollerini; bu süreçlerde gelişen beyinlerini etkileyebileceklerini fark etmeye başlamakta ve bu ilk yılları mutlu ve olumlu kılmak için ne gerekiyorsa yapmaktadırlar (Knoll, 2016). Ramos'un (2012, s. 78) ifadelerinde, kütüphane/ kütüphanecilerin dişında (şüphesiz onlarla koordineli olması beklenen) iki bağlamın rolüne yapılan vurgu, bu gerçeğin altını daha da çizmektedir. Söz konusu ifadelere göre, iki önemli bağlam; aile ve okul ilk okuma algılarının oluşturulmasına önemli oranda etki etmektedir. İlk okuma deneyimlerinin olumlu olması okuyanları motive ederken, tersine olumsuzluğu okuyucular ile kitaplar arasında sonraki yıllara da yayılacak biçimde engeller oluşturacaktır (Ramos, 2012, s. 78). Tüm bu bilgiler, bebeklerin zihinsel gelişiminde kütüphaneci, okul ve ailelerin tavır, tutum ve yaklaşımlarının önemini ortaya koymaktadır. 
Bebeklerin gelişimleri için gerekli olan fiziksel alanlar, eğitimleri için gerekli materyaller sağlanarak onlara uygun ortamlar tasarlanmaktadır. Ayrıca bu konuda bebekler için kitaplar yazılmaya ve konu derinlemesine incelenmeye başlanmıştır (Marino, 2003, s.1).

Bebeklere yönelik kütüphane hizmeti programları oluşturulmasının amaçları şu şekilde belirtilmektedir:

- Okuryazarlığı desteklemek,

- Bebeğin hayatının başlangıcından itibaren dil sevgisinin oluşturulması,

- Ebeveynler ve bakıcılar için bebeklere şarkı söylemenin, konuşmanın ve okumanın değerini ve gerekliliğini vurgulamak ve ebeveynlere bunu yapmanın en iyi yollarını modellemek (Marino, 2003, s.1).

Bebekler için kütüphane hizmetleri konusunda, kütüphaneler tarafından yapılabilecek basit uygulamaları Knoll şu şekilde sıralamıştır:

- Hastanelerle işbirliği kurulması, bebeğin ilk profesyonel eğitim sağlayıcısı olarak küçük bir hediye ve kütüphane iletişim bilgilerinin aileye verilmesi,

- Bebek oyunları, kitap etkileşimi ve bakıcılarla spontane görüşmeler için hazır olunmas1,

- Bebeklerin ve çocukların kelime dağarcığının gelişimini destekleyen kitaplar edinilmesi,

- Ebeveynlerin ve bakıcıların ilgilendiği konuları içiren (beslenme, hikâye zamanı vb.) programlar hazırlanmas1,

- Ev ziyaretleri için aile hizmetleri departmanları ve diğer topluluklara katılım,

- Çocuk kütüphaneciliği tarihi hakkında bilgi sahibi olunması,

- Çocuk gelişimi ile ilgili araştırmalardan haberdar olunması,

- Bilinmeyen bir kütüphanenin yanınızda bir bebekle ziyaret edilmesi ve deneyimlerin diğer personel ile tartışılarak bu konuda beyin fırtınası yapılması,

- Kütüphaneye henüz gelmemiş genç ailelere davetiye gönderilmesi (Knoll, 2016).

Kütüphaneler dışında ilişkili meslek örgütleri, eğitim kurumları/bölümler ve kütüphanelerin bağlı olduğu kurumlara sunulan öneriler ise şu şekildedir:

- Eğitim kurumlarındaki ilişkili bölümlerde lisans düzeyinde ders programlarına bebek ve çocuk gelişimi, aile dinamikleri, temel sosyal hizmetler gibi konuların eklenmesi,

- Çocuk kütüphaneciliğinin ülkeye ve nüfusa olan katkılarının topluma yayılması,

- Bebeklere ve küçük çocuklara özgü kaliteli bir hizmet için çocuk gelişimi konusunda uzman kütüphanecilerin çalışması (Knoll, 2016). 
IFLA tarafından hazırlanan "Bebekler ve Küçük Çocuklar için Kütüphane Hizmetleri Rehberi”ne göre; bebekler için hizmetler tasarlanırken, ebeveynlerin de kütüphane içerisinde vakit geçirebilecekleri (müzik, yaratıcı drama merkezleri, ev bakımı, fiziksel oyun alanları vb.) alanlar unutulmamalıdır. Ayrıca bebekler için tekerlemeler, ninniler, şarkılar, resimli kitaplar ve öykü anlatımları gibi konuşma gelişimlerini desteklemede önemli rol oynayan etkinlikler planlanmalıdır (IFLA, t.y., s. 6).

Hizmetler dışında bebekler için kütüphaneye sağlanacak materyaller hem güvenlik hem de çocuğun gelişimi açısından önem arz etmektedir. Bu nedenle çocuğun yaşına ve gelişimine uygun materyallerin seçilmesi gerekmektedir. Bebekler için resimli, kumaş ve dokun-hisset gibi duyusal kitapların tercih edilmesi uygun olacaktır (IFLA, t.y., s.7).

Kütüphanelerde bebekler için hizmet tasarlanırken, ortam, araç, gereç ve materyallerin tehlikeli olmamasına ve güvenliğe önem verilmelidir. Mobilyaların tasarımı ve düzeni tehlike yaratacak biçimde olmamal, oyuncak gibi materyallerin temizliğine dikkat edilmelidir. Daha ergonomik olması ve ebeveynlerin ulaşımı açısından yüksek binalarda asansör bulunmalıdır. Bebeklere hizmet sunan kütüphanelerde oyun ve oyuncak bölümünün olması; bu bölümlerin halı ile kaplı olması; ayrıca bebek bakım odasının yer alması önemli unsurlar arasındadır (IFLA, t.y., s.7).

Aşağıda yurtdışında yer alan bebek dostu kütüphanelere birkaç örnek görsel sunulmuştur. $\mathrm{Bu}$ görsellerde bebeklerin kimi zaman bireysel kimi zaman ise ebeveynleri ile etkinlikler yaptıkları ve kütüphanelerin onlar için sunduğu güvenli ortam dikkati çekmektedir.

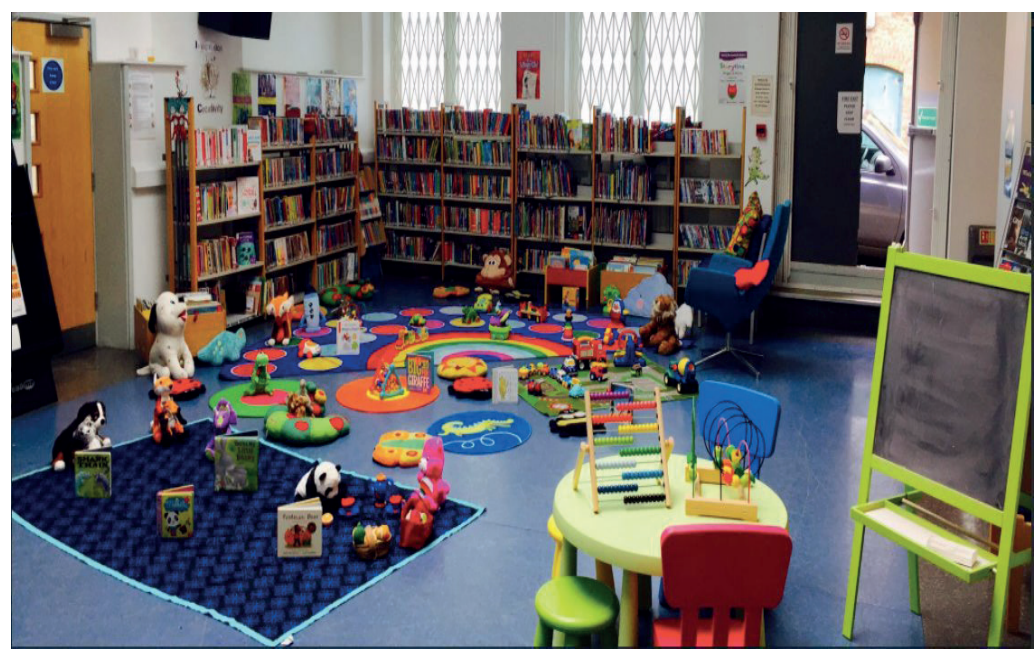

Resim 1: West Norwood Kütüphanesi (Londra, İngiltere) 


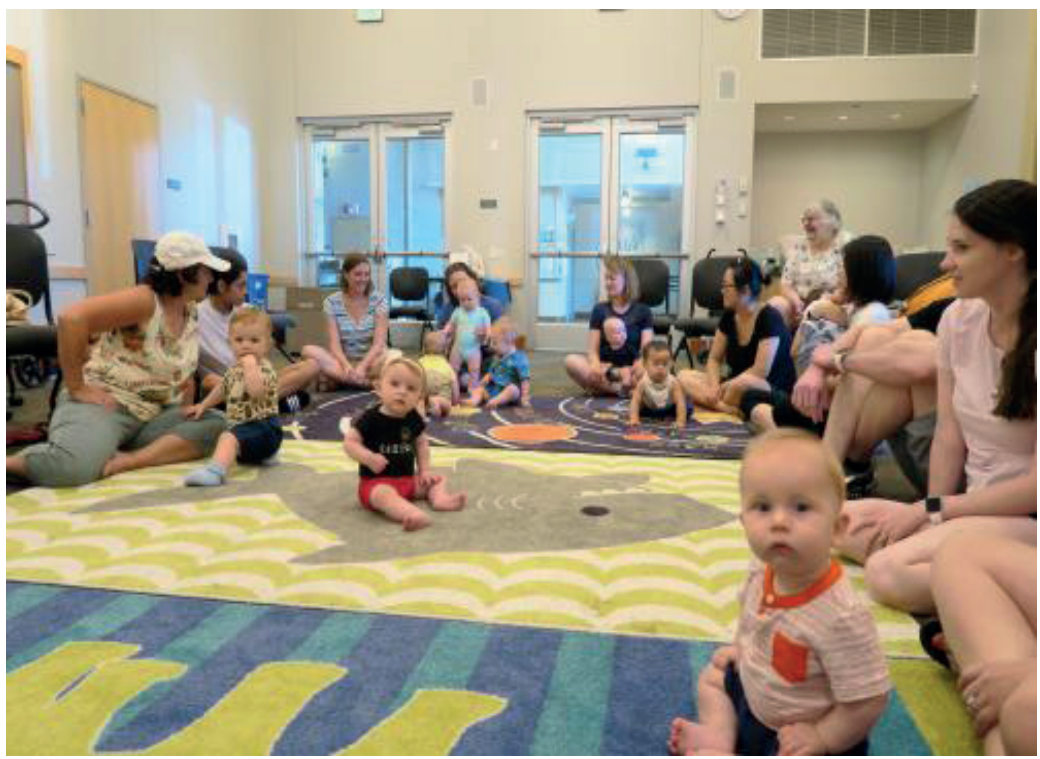

Resim 2: Tualitin Halk Kütüphanesi (Oregon, ABD)

\section{Türkiye'de Halk Kütüphanelerinde Kurulan Bebek Kitaplıkları / Bölümleri}

Çocuk kütüphaneleri, 2000 yılının sonlarında halk kütüphanelerine devredilmiştir (Demircan, 2006, s. 177). İlk olarak 1920-1930 y1lları arasında çocuk kütüphanelerinin gerekliliği fark edilmiş ve ilk çocuk kütüphanesi 1925 yılında Türk Ocakları tarafından Akhisar'da kurulmuştur (Gönen, Temiz, Akbaş, 2015, s. 78). Açılan ilk çocuk kütüphanesinin ardından Manisa Halkevi'nde bir çocuk kütüphanesi daha kurulmuştur (Sağlamtunç, 1998, s. 75). Bakırköy Halk Kütüphanesinde ise ilk kez modern bir anlayışla 1979-1980 yıllarında hizmete giren "Örnek Çocuk Kütüphanesi” kurulmuş ve burada okul öncesi çocuk bölümü açılmıştır (Sağlamtunç, 1998, s. 78). Bu ilk girişimler ile birlikte çocuk kütüphanelerinin sayısı sürekli artış göstermiştir. Bu artış zamanla değişim göstermiştir. 1966 y1lında 179 olan çocuk kütüphanelerinin sayısı 1974 yılında 286, 1979 yılında 296 sayısına ulaşmış; 1986 yılında gelindiğinde ise ciddi bir düşüş yaşayarak 106'ya kadar düşmüştür (Odabaş ve Akkaya, 2019, s. 94). 2000 yılına gelindiğinde Halk Kütüphanelerine devredilen çocuk kütüphane sayısı 72 olarak bilinmektedir (Demircan, 2006, s. 179).

2000 yılında Halk kütüphanelerinde devredilen çocuk kütüphaneleri Kültür ve Turizm Bakanlığı Kütüphaneler ve Yayımlar Genel Müdürlüğü bünyesinde hizmet sunmaya başlamıştır.

Çocuk Kütüphaneleri halk kütüphaneleri dışında tüzel ya da gerçek kişiler tarafından kurulabilmektedir. Çocuk kütüphaneleri kurulmasına ilişkin başlıca yasal belgeleri Yılmaz (2019a, s. 15) şu şekilde belirtmiştir: 
- Birleşmiş Milletler Çocuk Haklarına Dair Sözleşme (1989).

- 5216 sayılı Büyükşehir Belediyesi Kanunu (2004).

- Kültür ve Turizm Bakanlığı Yayın Seçme Yönetmeliği (2005).

- 5393 Sayılı Belediye Kanunu (2005).

- Kültür ve Turizm Bakanlığı Halk Kütüphaneleri Yönetmeliği (2012).

- Kültür ve Turizm Bakanlığı Hizmet Esasları Genelgesi (2012a).

- T.C. Anayasa ve diğer yasa ve yönetmelikler.

Adı geçen belgelerin bir kısmı, kütüphane kurmayla doğrudan ilişkili gözükmese de yeni kurulacak ya da hizmet sunmakta olan çocuk kütüphaneleri için kullanılabilecek olası yasal belgelerdir.

Çocuk kütüphanelerine ilişkin ayrı bir yönetmelik bulunmamaktadır. Ancak 1982 yılında yayınlanan "Halk ve Çocuk Kütüphaneleri Yönetmeliğì” incelendiğinde, "Çocuk Bölümü - Çocuk Kütüphanesi” (9. madde) olarak geçmektedir. Yeni yönetmelikte (2012) bu bölüm kaldırılmıştır. Her iki yönetmelikte de, çocuk kütüphanesine ilişkin hizmetler diğer başlıklar altında ayrı ayrı ele alınmıştır.

Çocuk kütüphaneleri ilk kuruldukları biçimi ile okuma eylemi için hizmet sunmanın yanında ebeveynlere, aile fertlerine, bakıcılara ve farklı yaş gruplarına zengin hizmet sunan bir yapıya dönüşmüştür (Odabaş ve Akkaya, 2019, s. 84). Bu farklı yaş gruplarının arasında bebek kullanıcı grubu da yer almaktadır.

Ülkemizde bebeklere yönelik hizmet sunan 3 kütüphane olduğu bilinmektedir. Bunlardan birisi Tokat Valiliği’ne bağlı ve müstakil olarak hizmet veren "Bebek Kütüphanesi” ismiyle açılmıştır. İkincisi Karabük İl Halk Kütüphanesi bünyesinde hizmet sunan bebek bölümü, üçüncü ise Tekirdağ Şarköy İlçe Halk Kütüphanesi bünyesinde yer alan çocuk bölümüdür (Haber Arşivi, 2019). Çalışma kapsamı IFLA ilkeleri doğrultusunda Halk Kütüphanelerine bağlı bebek bölümlerini içerdiğinden, Tekirdağ ve Karabük örnekleri değerlendirilmiştir. Çalışma örneklemi belirlenirken Halk Kütüphanesi bünyesinde hizmet sunan kütüphaneler tercih edildiğinden Tokat Valiliği'ne bağlı olarak hizmet sunan bebek kütüphanesi çalışmanın dışında bırakılmıştır.

\subsection{Zübeyde Hanım İl Halk Kütüphanesi ve Şarköy İlçe Halk Kütüphanesi: Bebek Bölümü}

Bebeklere yönelik hizmet sunma amac1yla "Bebek Kütüphanesi” ismiyle Karabük Zübeyde Hanım İl Halk kütüphanesine bağlı olarak 2018 yılında hizmete açılmıştır. Bebeklere yönelik ilk eğitim programları ise Kasım 2019 itibariyle başlamıştır (Etkinlikler, 2019). 
Tekirdağ Şarköy'de bulunan ilçe halk kütüphanesi tarafindan oluşturulan bebek bölümü 2019 yılı haziran ayında hizmete açılmıştır (Haberler, 2019)

Her iki kütüphane de halk kütüphanesi içerisinde bir bölüm olarak hizmete sunulmuştur. Aşağıda bu kütüphanelere ilişkin birkaç görsel yer almaktadır.

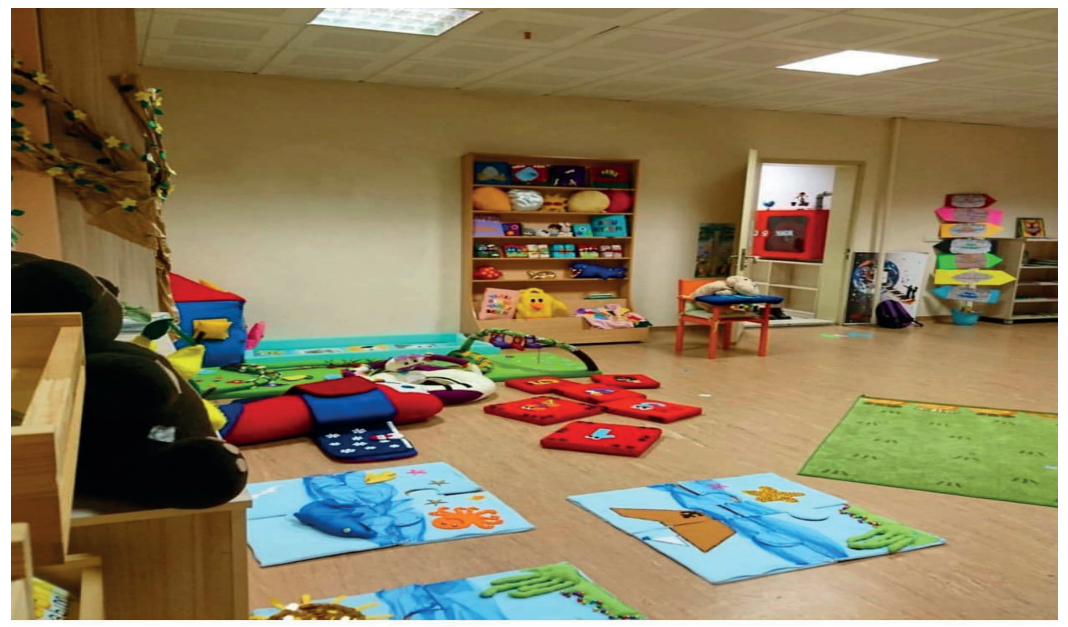

Resim 3: Karabük Zübeyde Hanım İl Halk Kütüphanesi Bebek Bölümü 1

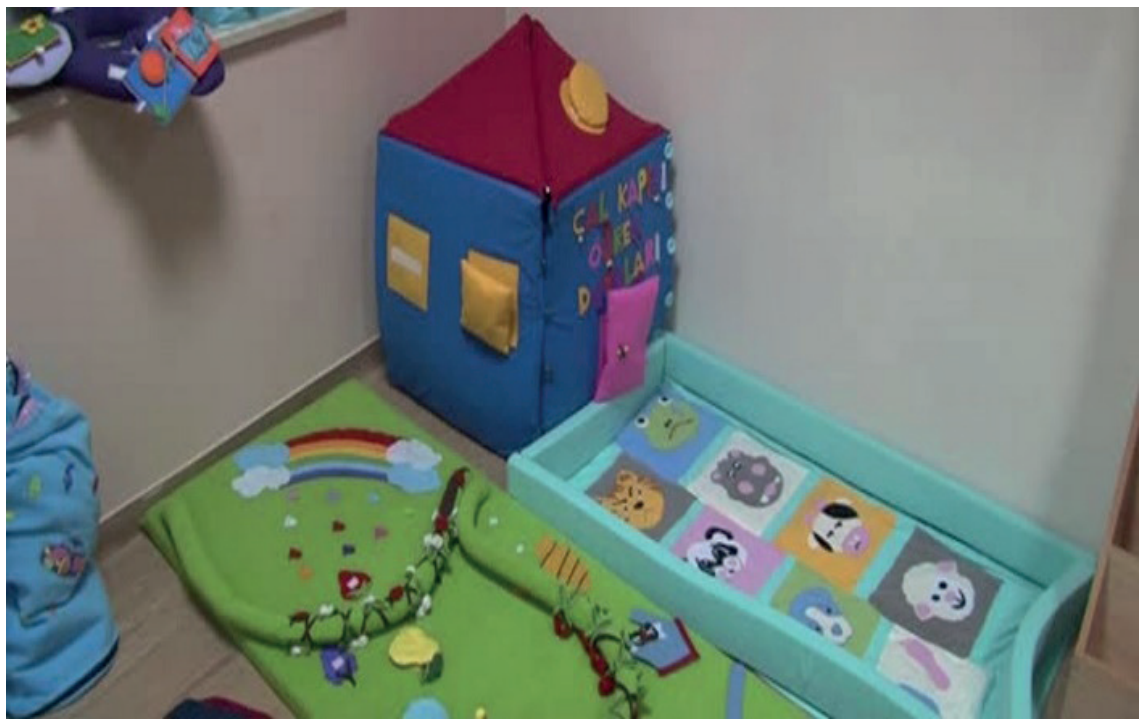

Resim 4: Karabük Zübeyde Hanım İl Halk Kütüphanesi Bebek Bölümü 2 


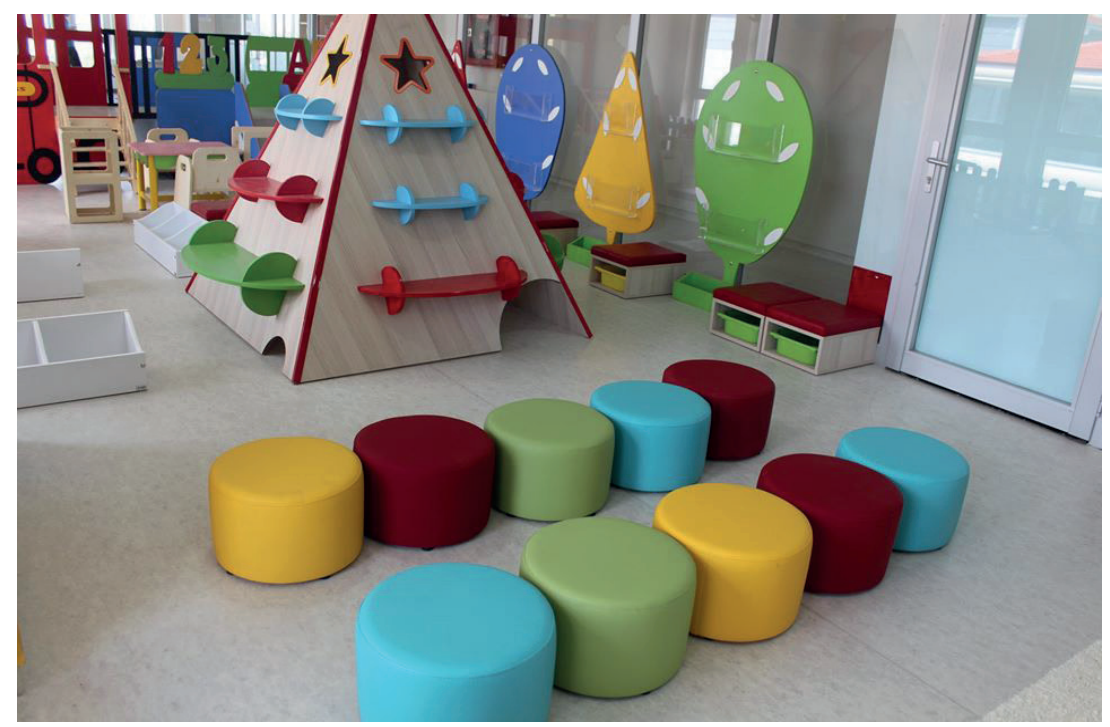

Resim 5: Şarköy İlçe Halk Kütüphanesi Bebek Bölümü 1

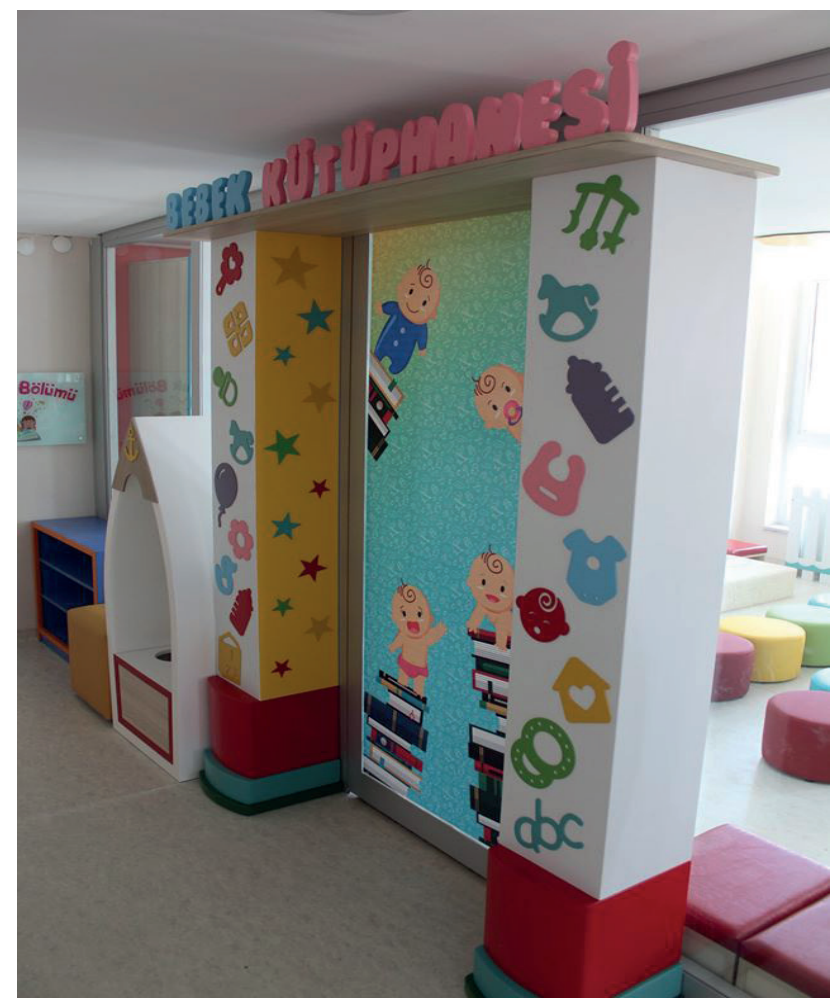

Resim 6: Şarköy İlçe Halk Kütüphanesi Bebek Bölümü 2 


\subsubsection{Yöntem, Bulgular ve Yorum}

Çalışma kapsamında nitel araştırma yapılmıştır. Nitel araştırma kapsamında durum çalışması, veri toplama tekniği olarak ise yapılandırılmış görüşme ve doküman incelemesi teknikleri uygulanmıştır. Yine çalışma kapsamında 2 halk kütüphanesinin Bebek Bölümleri incelenmiştir. 12 sorudan oluşan yapılandırılmış görüşme soruları 2 kütüphane yöneticisine de (Şarköy İlçe Halk Kütüphanesi ve Zübeyde Hanım İl Halk Kütüphanesi) e-posta aracılığıyla gönderilmiş ve veriler e-posta yoluyla toplanmıştır.

Kütüphane yöneticilerine yöneltilen sorular kütüphanenin bebek bölümüne ilişkin veri toplamak amacıyla oluşturulmuştur. Soruların genel kapsamı şu şekildedir: Bebek bölümünün hizmete açılma zamanı, personel sayıları ve nitelikleri, kütüphaneyi kullanan bebek sayısı, mekân tasarımı, güvenlik ve bebek bakım olanakları, bütçe ve kullanıcılardan alınan geribildirimler. İki kütüphane yöneticisinden alınan dönütler sonucunda veriler toplanmış ve analiz edilmiştir.

Verilerin analizinde ise betimsel analiz yöntemi uygulanmıştır. "Betimsel analiz, elde edilen verilerin daha önceden belirlenen temalara göre özetlendiği ve betimlendiği bir nitel veri analiz tekniği olarak tanımlanmaktadır." (Sığrı, 2018, s. 276). Bu kapsamda verilerin değerlendirilmesi amacıyla başlıklar belirlenmiş ve kütüphanelerin 5 temel unsuru (bütçe, mekân, personel, kullanıcı ve derme) bağlamında değerlendirilmiştir. Her iki kütüphanenin de yöneticileri bebek bölümlerine ilişkin gönderilen sorulara yanıt vermiştir. Alınan yanıtlar 1şı̆̆ında bebek bölümleri 5 temel unsur bağlamında değerlendirilerek aşağıdaki tabloda veriler sunulmuştur.

Tablo 1: Kütüphanelerin 5 unsur kapsamında incelenmesi

\begin{tabular}{|l|l|l|}
\hline & Karabük İl Halk Kütüphanesi & Şarköy İlçe Halk Kütüphanesi \\
\hline Mekân & $\begin{array}{l}\text { Mekân parke ve halı döşeli, bebek bakımı } \\
\text { odası bulunmaktadır. }\end{array}$ & $\begin{array}{l}\text { Mekânın tamamı oyun matı ile kaplı, bebek } \\
\text { bakımı için ayrı bir alan bulunmuyor. }\end{array}$ \\
\hline Perme & $\begin{array}{l}\text { Bebek kitapları, duyu eğitimi materyalleri, } \\
\text { ritim aletleri. }\end{array}$ & Kitap, görsel işitsel dokunsal materyaller. \\
\hline Bütçe & $\begin{array}{l}\text { Ayrı personel yok (Karabük Üniversitesi } \\
\text { Çocuk Gelişimi Bölümü’nün öğrencileri } \\
\text { ile işbirliği var). }\end{array}$ & Ayrı bir personeli yok \\
\hline Kullanıcı & Genel kütüphane bütçesi. & Genel kütüphane bütçesi. \\
\hline
\end{tabular}

Her 2 halk kütüphanesi de bebek bölümleri bağlamında değerlendirildiğinde, bu alanların bebekler için uygun olduğunu ancak Şarköy İlçe Halk Kütüphanesi'nin bebek bakımı için ayrı bir alanının olmamasının eksiklik olduğunu söyleyebiliriz. Bu da bebeklerin bakımı açısından ebeveynlerin sorun yaşaması ve kütüphaneyi uzun süre kullanamaması anlamına gelmektedir. 
Buna karşın Karabük İl Halk Kütüphanesinde bebek bölümünde ayrı bir personel olmaması olumsuz olarak değerlendirilirken, Karabük Üniversitesi Çocuk Gelişimi Bölümü ile işbirliği kurulması ve öğrencilerin kütüphanede etkinlikler düzenlemesi, işin uzmanları tarafından hazırlanan etkinliklerin yer alması olumlu bir durum olarak değerlendirilebilir.

Bu yanıtlar haricinde gelen geri bildirimlere baktığımızda, Şarköy İlçe Halk Kütüphanesini günde ortalama 6-7 bebek kullanıyorken, Karabük İl Halk Kütüphanesini ortalama 30 bebek kullanmaktadır. TÜİK 2018 yılı nüfus kayıt sistemine göre Karabük’te 0-4 yaş arası çocuk sayıs1 10,923 iken, Şarköy'de bu yaş grubunun sayısı 1,533 olarak gösterilmiştir (TÜİK, 2019). Kullanım oranlarındaki farkın nüfus dağılımının farklılığından kaynaklandığı söylenebilir. Şarköy’ün küçük bir ilçe olması ve Karabük'e göre 0-4 yaş arası çocuk sayısının neredeyse 1/10 oranında az olması bu sonucu ortaya koymaktadır. Bu bağlamda nüfus bazında incelendiğinde Şarköy’ün de yoğunlukla kullanıldığını söyleyebiliriz.

Bunun dışında kütüphanelere hizmetlerine ilişkin alınan geri bildirimler sorulduğunda, her iki kütüphane de olumlu yönde geri bildirim aldıklarını ve bu hizmetlerin genişletilmesi gerektiği yönünde talepler olduğunu dile getirmişlerdir. Ayrıca Karabük İl Halk Kütüphanesi, içinde bulundukları durumu şu şekilde özetlemiştir: "Arz oluşturduk, taleplere yetişmekte zorlaniyoruz".

Şarköy İlçe Halk Kütüphanesi ise annelerin "Dışarıda bebeğimizle gidebileceğimiz yerler yoktu, iyi ki böyle bir alan düşünülüp oluşturulmuş” şeklinde geri bildirimlerini aldığını bildirmiş. Buna ek olarak ise küçük ilçelerde bu tarz hizmetlerin, büyük illere göre daha anlamlı ve önemli olduğunu dile getirmiştir.

\section{SONUÇ VE ÖNERILER}

Halk kütüphanelerine bağlı olarak hizmet sunan çocuk kütüphaneleri, gelişen teknoloji ve eğitim yöntemleri ile birlikte hizmetlerinde değişime ve çeşitliliğe yönelmiştir. Son dönemlerde popüler olmaya başlayan "baby friendly libraries - bebek dostu kütüphaneler" kavramı ile birlikte kullanıcı grubu olarak bebekler ön plana çıkmıştır. Bu bağlamda bebeklere yönelik gerek mekânsal tasarım gerekse derme geliştirme konusunda çalışmalar yapılmıştır. Yaşanan bu gelişmeler ile birlikte çocuk kütüphaneleri bebek kullanıcıların ve ebeveynlerinin rahatlıkla gelip vakit geçirebilecekleri ortamlar halini almaya başlamıştır.

Çalışma kapsamında değerlendirilen, Karabük Zübeyde Hanım İl Halk Kütüphanesi ve Şarköy İlçe Halk Kütüphanesi bebek dostu kütüphane olgusunu gerçekleştiren ülkemizdeki ilk örneklerdir. Karabük Zübeyde Hanım İl Halk Kütüphanesi, Karabük Üniversitesi Çocuk Gelişimi Bölümü'nün de desteğini alarak iş birliği yolu ile bu hizmeti sunmaktadır. Bu durum hem derme yani bebeklerin materyalleri konusunda nitelikli ve zengin içerikli olmasını sağlamakta hem de sunulan hizmetin kalitesini arttırmaktadır. Ayrıca bebeklerin bakımı için ayrı bir alan 
bulunması, yine bu işbirliğinin bir sonucu olarak gösterilebilir. Çünkü alanında uzman kişilerin (Çocuk gelişimci, eğitimci, vb.) görüşü ile bu yaş grubu gereksinimleri daha net bir şekilde ortaya konularak gerekli düzenlemeler yapılmıştır. Şarköy İlçe Halk Kütüphanesinde ise küçük bir ilçede yer alması, olanaklarının sınırlı olması olumsuz yönleri olarak gösterilebilir. Küçük bir ilçede olmasına rağmen kullanım oranlarının fazla olması, o bölge için bu mekânın önemini ortaya koymaktadır. Bebek bakımı için ayrı bir alan olmaması bu kütüphanenin en önemli eksiği olarak gösterilebilir. Buna ek olarak Şarköy İlçe Halk Kütüphanesinde çalışan 1 kütüphaneci ve 1 Bilgisayar İşletmeni dışında personelleri olmadığından bu mekân için ayrı bir kişi görevlendirememişlerdir. Bu noktada personel sayısının az olması hizmetlerin kalitesi ve sürdürülebilirliği açısından olumsuz olarak değerlendirilebilmektedir. Her iki kütüphanenin de eksikleri olmasına karşın iş birliği ve paylaşımlarla geliştirilebilecek olan bu hizmetin ülkemizde ilk olarak sunmuş olmaları önem arz etmektedir.

Bebekli ailelerin ev dışında rahatlıkla bebeğiyle birlikte vakit geçirebileceği sosyal alanların, sağlıksız ortamlar olan kafe gibi mekânlar değil de kütüphaneler olması pek çok kazanımların sağlanmasına yol açmaktadır. Ebeveyn için sosyalleşme ve okuma bebeğin ise erken yaşta kütüphane kullanması gibi kazanımlar beraberinde olumlu gelişmeleri tetiklemektedir. Erken yaşta kütüphane ile tanışan bebekte hem erken okuryazarlık ve kitap okuma alışkanlığ becerilerinin gelişmesi hem okuma alışkanlığının daha çabuk, hızlı ve kolay gerçekleşebilmesi söz konusudur. Özellikle gelişmiş metropoller gibi daha fazla olanaklara sahip yerleşkeler yerine pek çok olanaktan görece yoksun olan küçük il ve ilçeler için düşünüldüğünde bu ve benzeri katkıların ne kadar önemli olduğu açık bir şekilde anlaşılır. Büyük şehirlerde ailelerin bebekleri ile gidebilecekleri birçok ortam olmasına karşın küçük yerlerde böyle olanaklar ya yok ya da çok sınırlıdır. Bu noktada halk kütüphanelerini sosyalleşme ve üçüncü mekân bağlamında ele aldığımızda bebekler için alanlar tasarlanmasının gerekliliği daha fazla kendini göstermektedir. Bu tür alanlarda tasarlanacak kütüphane hizmetlerine ilişkin pek çok unsur yerine getirilirken, bu hizmetlerin sürekliliğinin sağlanması adına temizlik konusuna da sürekli olarak dikkat edilmesi oldukça önemlidir. Unutulmamalıdır ki hizmet sunulan yaş grubunun sağlığı ve fiziksel gelişimi, bilişsel, ruhsal vb. pek çok alandaki gelişiminin temeli için gereklidir.

Bebeklik çağından itibaren kütüphane ortamında büyüyen bireyin kütüphaneyi doğal ortamı olarak görmesi iyi bir kütüphane kullanıcısı olmasını sağlayacaktır. Bebek bölümleri oluşturulurken dikkat edilmesi gereken noktalar şu şekilde sıralanabilir:

- Bebeklerin kullanabileceği özellik, boyut ve içeriklere sahip kitaplar ve materyaller tercih edilmeli.

- Mekân tasarımının çocukların ilgisini çekecek biçimde planlanmasının yanı sıra güvenliğine de dikkat edilmeli.

- Temizlik konusunda özen gösterilmeli. 
- Bebekler ve aileleri için farklı etkinlikler tasarlayarak ailelerin ve bebeklerin ilgisi çekilmeli.

- Kütüphanelerde bu alanların varlığı etkinliklerle duyurulmalı.

- Bebeklerin bakımları için gerekli alanlar tasarlanmalıdır.

Hakem Değerlendirmesi: Dış bağımsız.

Çıkar Çatışması: Yazarlar çıkar çatışması bildirmemiştir.

Finansal Destek: Yazarlar bu çalışma için finansal destek almadığını beyan etmiştir.

Peer-review: Externally peer-reviewed.

Conflict of Interest: The authors have no conflict of interest to declare.

Grant Support: The authors declared that this study has received no financial support.

\section{Kaynakça/References}

[Karabük Zübeyde Hanım İl Halk Kütüphanesi Bebek Bölümü 1 fotoğrafi]. (t. y.). Erişim Adresi: http://www. okumaajansi.com/turkiyenin-ilk-bebek-kutuphanesi-karabukte-acildi/

[Karabük Zübeyde Hanım İl Halk Kütüphanesi Bebek Bölümü 2 fotoğrafi]. (t. y.). Erişim Adresi: https://www. sondakika.com/haber/haber-turkiye-nin-ilk-bebek-kutuphanesi-karabuk-te-11482672/

[Şarköy İlçe Halk Kütüphanesi Bebek Bölümü 1 fotoğrafi]. (t. y.). Erişim Adresi: https://www.facebook. com/926503514129335/photos/a.928186080627745/2093613100751698/?type=3\&theater

[Şarköy İlçe Halk Kütüphanesi Bebek Bölümü 2 fotoğrafi]. (t. y.). Erişim Adresi: https://www.facebook. com/926503514129335/photos/a.928186080627745/2093612980751710/?type=3\&theater

[Tualitin Halk Kütüphanesinin fotoğrafi]. (t. y.). Oregon, ABD. Erişim Adresi: https://www.tualatinoregon. gov/library/book-babies-storytime-1

[West Norwood Kütüphanesinin fotoğrafi]. (t. y.). Londra, İngiltere. Erişim adresi: https://images.app.goo.gl/ vrYaAnCHxVvmfG4J9

Adrese Dayalı Nüfus Kayıt Sistemi Sonuçları, 2019. (2020, Ocak). Türkiye İstatistik Kurumu Haber Bülteni, 33705. Erişim Adresi: https://biruni.tuik.gov.tr/medas/?kn=95\&locale=tr

Bacanlı, H. (2011). Eğitim psikolojisi. Ankara: Pegem.

Bertan, M., Haznedaroğlu, D., Yurdakök, K., ve Güçiz, B. D. (2009). Ülkemizde erken çocukluk gelişimine ilişkin yapılan çalışmaların derlenmesi (2000-2007). Çocuk Sağlı̆̆l ve Hastalıkları Dergisi, 52(1), 1-8.

Biblarz, D., Bosch, S. ve Sugnet, C. (2001). Guide to library user needs assessment for integrated information resource management and collection development. London: The Scarecrow Press, Inc.

Birleşmiş Milletler çocuk haklarına dair sözleşmesi. (1989, 20 Kasım). Erişim Adresi: http://cocukhaklari. barobirlik.org.tr/dokuman/mevzuat_uamevzuat/birlesmismilletler.pdf

Campbell, H.C. (1992). Halk kütüphanesi sistem ve hizmetlerinin geliştirilmesi (B. Çapar, Çev.). Ankara: Kültür Bakanlığ1 (Orijinali 1983’te yayımlanmıştır). Erişim adresi: http://www.kygm.gov.tr/TR,986/halkkutuphanesi-sistem-ve-hizmetleriningelistirilmesi.html 
Cengiz, E. (2017). Halk kütüphanelerinde derme geliştirme politikalarl: Türkiye'de halk kütüphaneleri üzerine bir değerlendirme (Yayımlanmamış yüksek lisans tezi). Hacettepe Üniversitesi, Ankara.

Çadem. (2019). Çocuk gelişim dönemleri. Erişim Adresi: https://www.cadempsikoloji.com/blog/posts/cocukgelisim-donemleri

Demircan, C. (2006). Türkiye'deki çocuk kütüphanelerinin halk kütüphanelerine devredilmelerinden önceki niceliksel durum 1995-2000. Türk Kütüphaneciliği, 20(2), 177-194.

Durakoğlu, A. (2011). Maria Montessori’ye göre okul öncesi çocukluk döneminin özellikleri. Dicle Üniversitesi Ziya Gökalp Ĕ̈itim Fakültesi Dergisi, (16), 133-145.

Ersoy, O. (1983). Halk kütüphaneleri. Türk Kütüphaneciliği, 32(1), 1-4.

Gill, P. (2004). Halk kütüphanesi hizmeti: Gelişim için IFLA/UNESCO ilkeleri. B. Yılmaz (Çev.). İstanbul: TKD İstanbul Şubesi.

Gönen, M., Temiz, N. ve Akbaş, S. C. (2015). Erken çocukluk döneminde çocuk kütüphanelerinin rolü ve önemi: Bir kütüphane programı örneği. Milli Eğitim Dergisi, 45(208), 76-89.

Güller, E.D. ve Bilbay, P. (2016). Kütüphane yapılarında okul öncesi çocuklara yönelik interaktif mekanların irdelenmesi. Türk Kütüphaneciliği, 30(3), 398-414.

Gürbüz, M. (2015). İlk Kitabım ve Hazine Sandığım Projesi ve Türkiye için öneriler. Türk Kütüphaneciliği, 29(1), 170-178.

IFLA (t.y.). Bebekler ve küçük çocuklar için kütüphane hizmetleri rehberi (M. Gürbüz ve S.Ekici, Çev.). Erişim adresi: https://www.ifla.org/files/assets/hq/publications/professional-report/100-tr.pdf

Işıkoğlu E. N. (2016). Erken çocukluk döneminde kütüphane ve dil gelişimi. VIII. Eğitim Araş̧tırmaları Kongresi. 5-8 Mayıs 2016 Çanakkale 18 Mart Üniversitesi. Erişim Adresi: https://www.researchgate.net/profile/ Nesrin_Isikoglu_Erdogan/publication/313108943_Erken_Cocukluk_Doneminde_Kutuphane_ve_Dil_ Gelisimi/links/58908ec3aca272bc14be523a/Erken-Cocukluk-Doeneminde-Kuetuephane-ve-Dil-Gelisimi.pdf

Knoll, D. J.(2016). Engaging babies in the library: Putting theory into practice. Erişim Adresi: https:// americanlibrariesmagazine.org/2016/05/31/engaging-babies-library-childrens-librarians/

Kol, S. (2011). Erken çocuklukta bilişsel gelişim ve dil gelişimi. Sakarya Üniversitesi Eğitim Fakültesi Dergisi, 21(21), 1-21.

KYGM. (2012). Kütüphane hizmet esasları. Erişim Adresi: https://kygm.ktb.gov.tr/Eklenti/4832,khgenelge-17.pdf?0

KYGM. (2017). Halk kütüphanelerinde mimari uygulamalar çalıştayı 7-9 Aralık 2017. Ankara: Kütüphaneler ve Yayımlar Genel Müdürlüğü.

Marino, J. (2003). Babies in the library. Oxford: The Scarecraw Press.

McKechnie, L. (2006). Observations of babies and toddlers in library settings, Library Trends, 55(1), 190-201.

MEGEP (2009). Çocuk gelişsimi ve eğitimi çocuğun gelişimi. Ankara: M.E.B.

Naylor, A. P. (1987). Reaching all children: A public library dilemma. Library Trends, 35(3), 369-392.

Odabaş, H. ve Akkaya, M. A. (2019). Kütüphane deneyiminin beşiği olarak çocuk kütüphaneleri. H. Odabaş, M. A. Akkaya (Ed.), Bilgi Merkezleri (s. 82-125) içinde. İstanbul: Hiper Yayın

Özdemirci, F. (1989). Türk bütçe sistemi ve halk kütüphanelerine yansıması (Yayımlanmamış yüksek lisans tezi). Ankara Üniversitesi, Ankara.

Özlük, H. K. (2006). Halk kütüphanesi kullanıcılarının bilgi arama davranışları (Yayımlanmamış yüksek lisans tezi). Ankara Üniversitesi, Ankara. 
Ramazan, O., ve Demir, S. (2011). Okul öncesi eğitim kurumuna devam eden 36-48 aylık çocukların bilişsel gelişim düzeyleri. Eğitim Bilimleri Araştırmaları Dergisi, 1(2), 83-98.

Ramos, A. M. (2012). Learning to read before you walk: Portuguese libraries for babies and toddlers. IFLA Journal, 38(1), 78-85. Erişim adresi: https://www.ifla.org/files/assets/hq/publications/ifla-journal/iflajournal-38-1_2012.pdf

Rankin, C. (2016). Introduction: Library services for the early years, Library Trends, 65(1), 1-4.

Rowley, J. (2000). From users to customers?. OCLC System \& Services, 16(4), 157-167.

Sağlamtunç, T. (1998). Türkiye'de çocuk ve halk kütüphaneleri. B. Onur (Yay. haz.). Cumhuriyet ve çocuk - II. Ulusal Çocuk Kültürü Kongresi Bildirileri 4-6 Kasım 1998 içinde (s. 73-83). Ankara: Ankara Üniversitesi, ÇOKAUM.

Sağlamtunç. T. (1994). Çağdaş kütüphanecilik ve düşünce özgürlüğü üzerine. İstanbul: Yapı tasarım.

Sığrı, Ü. (2018). Nitel araştırma yöntemleri. Ankara: Beta Basım Yayın.

Tekirdağ'da 0-3 yaş bebek kütüphanesi açıldı. (2019). Erişim Adresi: https://www.haberler.com/tekirdag-da0-3-yas-bebek-kutuphanesi-acildi-12185857-haberi/

Torun, O. (2018). Halk kütüphanelerinde yenilikçi yaklaşımlar. H. Odabaş ve M. A. Akkaya (Ed.). Halk kütüphaneleri: Geçmişten geleceğe yönelimler ve yeni roller içinde (s. 223-282). İstanbul: Hiper Yayın.

Türkiye'nin ilk bebek kütüphanesi Karabük'te açıldı. (2019). Erişim Adresi: http://karabuk.kutuphane.gov.tr/ TR-230793/turkiye39nin-ilk-bebek-kutuphanesi-karabuk39te-acildi.html

Türkiye'nin ilk müstakil bebek kütüphanesi hizmete girdi. (2019). Erişim Adresi: https://basin.ktb.gov.tr/TR243700/turkiye39nin-ilk-mustakil-bebek-kutuphanesi-hizmete-gir-.html

Türkiye’nin ilk ‘Bebek Kütüphaneleri Çalıştayı' KARABÜK’te. (2019). Erişim Adresi: https://karabuk.ktb. gov.tr/TR-244098/turkiye39nin-ilk-39bebek-kutuphaneleri-calistayi39-kara-.html

Uçak, Ö. N., ve Topçu, Ö. Ş. (2012). Günlük yaşamda bilgi gereksinimi ve halk kütüphaneleri. Erişim Adresi: http:/www.openaccess.hacettepe.edu.tr:8080/xmlui/bitstream/handle/11655/11701/ut.pdf?sequence=1

Yılmaz, B. ve Ekici, S. (2011). Çocuk kütüphanesi hizmetleri için ilkeler. Türk Kütüphaneciliği, 25(4), 545-552.

Yılmaz, E. (2011). Etkin kütüphane kullanımı önünde büyük bir engel olarak kütüphane kaygısı: Genel bir değerlendirme. Türk Kütüphaneciliği, 25(3), 371-416.

Yılmaz, B. (2019a, 4 Ekim). "Bebek kütüphanesi” kavramı ve yaklaşımı üzerine.[Blog yazısı]. Erişim Adresi: https://www.bbyhaber.com/bby/2019/10/04/bebek-kutuphanesi-kavrami-ve-yaklasimi-uzerine-prof-drbulent-yilmaz

Yılmaz, B. (2019b). Çocuk kütüphanesi hizmetleri kılavuzu. İstanbul: Hiper Yayın

Young, H. (Ed.). (1983). The ALA glossary of library and information science. Chicago: American Library Association 